\title{
Judging Contemporary Poems: Criteria and the Editor
}

\author{
John Hobbs
}

Many people think and talk about judging poems. Fewer actually do it, and these are usually editors. At its best editing is a self-effacing activity. The editor selects and presents, showing his literary criteria by example, not arguing the reader into appreciation as the critic often does. By this silence, however, judging can take on more mystery than it deserves. Put simply, those who judge routinely seldom theorize about it, and those who do theorize about judging rarely judge. Perhaps for good reason, since judging poems tends to be an intuitive process. The editor's intuitions need sound critical foundations, but because judgments don't require reasons submitted as proof, intuition can be a reliable and useful tool without being analyzed. To connect the theory of judging poems with its practice, I will first describe how the editors of one poetry magazine make their choices, then I'll try to suggest criteria implicit in their judging, and finally ask if contemporary poems require special standards or approaches in judging.

\section{How the editors of one magazine choose poems}

Poetry editing has many forms: the publisher's reader selecting manuscripts, the anthologist for school or general readers, the editors of little magazines, regular and respectable like Poetry or iconoclastic and occasional like Bly's The Seventies. Field falls somewhere between these two, neither Establishment nor eccentric (or so we hope). During its four years Field has attracted a small but devoted national audience by publishing poems by Stafford, Kinnell, Levertov, Simic, Rich, Bly among others and European poetry in translation. I use Field as my case study, not because it is special or even typical, but because I know its editing at first hand. A few more details may help the reader visualize our situation. Field has a chief editor and three or four associate editors (all but one published poets). Every poem is accepted by majority vote, a safeguard against eccentric judgments. Like most poetry magazines, we print just a tiny percentage of the submissions we receive. Our supply just equals our demand. Twice a year we collect enough poems to fill an eighty-page issue, but we couldn't fill a third issue without either better submissions or lower standards. Like panning for gold, the search can be tedious, the discard monumental, but the prize may be enough to live on until the next find.

Our search procedures are simple. Two editors go through all submissions to put aside the most unlikely prospects, saving on reading time for the other editors. Next, before our biweekly meeting, each editor reads through the remainder (perhaps 3-5 poems each by some 20 poets), noting his preferences for discussion later. At this first stage an editor reads quickly, looking for individual voices, strong openings and fresh images. Successful poems can emerge then, but more 
likely is a general impression of a poet's work. Because he has to read so many poems, an editor looks for originality, automatically rejecting conventional topics and tones. During this hurried moving from one poetic world to the next, the editor may find it hard to keep his poetic standards in mind. To help he may have a few key poems for mental reference, as Matthew Arnold used his famous "touchstones," but they won't match some kinds of poems at all.

At the editorial meeting an editor reads aloud the poets listed by one or more editors (perhaps one-third of those read at the first stage). Through experience we have learned to value this reading aloud, however hard the poem may be to follow. Reading poems with the eye alone, you can and do skip here and there, glancing by the weaker lines. The reader's attention is selective then, and he's looking for certain qualities. In contrast, the ear must hear every word. It is remarkable how many otherwise striking poems cannot pass this simple test. Many of the editors' first loves evaporate right here. The reader's interpretation of a poem can affect our response, so one editor normally reads all the poems aloud. We hear each poem in the same voice to make comparisons easier.

After our first year of editorial apprenticeship, we found that agreement on the best poems is quick, unanimous and sure. Little discussion is needed to reach a consensus. Marginal poems are the ones that produce split votes, while neither obviously successful nor unsuccessful poems prompt much analysis. To focus our disagreement, one editor will explain what he finds valuable in a poem and attempt to convince the others. That he seldom succeeds beyond convincing himself about his own preference may say less about our editors' critical abilities than about the intuitive nature of judgment when it works well. The more explaining a poem takes, the more likely it is to be marginally successful. Paradoxically, these are the poems we come to understand most thoroughly before rejecting them. We accept many poems that we cannot explain in detail, although not without feeling they are ultimately intelligible after study.

When we do analyze a poem, the differences in our critical languages impede communication. This may indicate that our intuitive agreements proceed from different reasons, or more likely that we fall back on critical terms learned here and there that don't really fit the poem or our sense of it. The Field editors do have different interests that do not overlap much at their extremes. One may favor the metaphysical lyric, for example; another looks for confessional honesty, while yet another likes formal experimentation. A poem that pleases all four editors must have a quality that links these different tastes in transcending each one of them.

During our first year, the editors felt a need for explicit criteria for poems, but we never got the list made, perhaps sensing it would be hard to agree and that it wasn't essential for judging anyway. Some poetry magazines begin with a public manifesto and maintain strong editorial opinions throughout. Because the only thing we're rebelling against is mediocrity in contemporary poetry, Field has avoided such declarations. That we did not state our purposes publicly doesn't mean the editors lack criteria-only that they are implied in the poems chosen. Two of them come first and are very general: Does the poem interest me? Do I 
learn anything from it? These are crucial because two negative answers end the judging process right there.

Another way to ask the interest question is: Do I want to reread the poem? Some poems may be enjoyable the first time through, but there is little impulse to return to them, to deepen the experience. This lack of involvement has long been a problem to many who approach poetry. The scope of the poem is often limited in ways the novel and play are not. It can present an insight, a moment, an action by one person, but it has trouble with a sequence of actions, a year, and many diverse insights. Four hundred years of English poetry have seen many possibilities worked through to the point of exhaustion. Because of this limited scope and weighty tradition, writing poems today takes special imagination and daring. Yet so much contemporary poetry lacks interest to anyone but its writer (sometimes even the parental bond looks suspect). Poetry remains a minority art today for many reasons, publishing economics, reading habits and bad education among them. Dullness is unfortunately one of these reasons. Poetry that has nothing important to say to contemporary readers will not be read. Dullness, not lack of skill, handicaps the majority of poems Field and other magazines receive.

The question "Do I learn something from the poem" relates to the interest question. If the poems interests us, that means that we learn something from it (and vice versa). Maybe we won't be able to say precisely what we do learn, but if a poem both connects to the reader's experience of life and extends it through imagination and reflection, he knows he has traveled with it. Thus, the poem must say something new to the reader, or say familiar things in a new way. This general criterion excludes all the poems that endlessly ruminate over the same commonplace ideas and situations. The successful poem must be unique too in a positive way, not just odd or unnatural. This insistence on new insight is not the same as novelty or fashion. What strikes one reader as new may, of course, be old hat to another. Applying criteria demands judgment even as it guides one's decision on a poem. The criteria of interest and learning are admittedly vague and subjective, yet if used carefully they are reasonable first tests for a poem, since they decide whether the reader wants to explore the poem any further. If he does, then more precise criteria can be used. First, we want to know whether the poem has value, second, where that value resides and by what changes it could be maximized.

\section{Criteria implicit in our judgments}

Some questions arise repeatedly when the Field editors discuss poems. The first nine are technical; the last four are more general in their scope. Not all of them would apply to any one poem, of course. As examples, I have tried to find brief poems that could be quoted in their entirety.

1. Is the line used as an interesting rhythmic unit? (Compare the mechanical regularity of "The Pine Bough" with the varied line in "The Cuttings." The last part of "The Red Door" is little more than divided prose.) 


\section{The Pine Bough}

I saw a thing, and stopped to wonder-

For who had set the moment when

The pine bough should dip out from under

The white oppressor's arm of snow,

And upward fling itself, as though

Attracted to a blue May heaven?

\section{The Cuttings}

Sticks-in-a-drowse droop over sugary loam,

Their intricate stem-fur dries;

But still the delicate slips keep coaxing up water;

The small cells bulge;

One nub of growth

Nudges a sand-crumb loose,

Pokes through a musty sheath

Its pale tendrilous horn.

\section{The Red Door}

iii

Depressed, we descend,

open the door, and walk out into

the blue-chip Indiana afternoon.

A moment I stop

on the stoop and to lighten our mood

play at wooden Indian.

In offering to the local gods

I hold out two cigars, a pencil, and a plastic pen ...

2. Does the poet use sounds to strengthen meaning or for their own sake? ("The Crucifix" is loud and heavy throughout. "The Well of Holy Heaven" is quieter but still obtrusive in its echoing. "Full Moon and Little Frieda" shows attention to sound effects but without exaggeration.)

The Crucifix

How dry time screaks in its fat axle-grease, As spare November strikes us through the ice

And the Leviathan breaks water in the rice

Fields, at the poles, at the hot gates to Greece;

It's time: the old unmastered lion roars 
And ramps like a mad dog outside the doors, Snapping at gobbets in my thumbless hand...

The Well of Holy Heaven

The apple of the daisy knows it's true: the earth is, after, all, a world, though tantamount to tangerines-equal in value to a curlew's call, a cell of bees in amber comb, the curl of water, welter of the summer sunning autumn's falls.

Full Moon and Little Frieda

A cool small evening shrunk to a dog bark and the clank of a bucket-

And you listening.

A spider's web, tense for the dew's touch.

A pail lifted, still and brimming-mirror

To tempt the first star to a tremor ...

3. Does the poet use tired or energetic words? (Compare the vague remoteness of "Storm's Timeless Augury" with the immediacy of diction and experience in "Mid-Country Blow.")

\title{
Storm's Timeless Augury
}

\author{
Storm's timeless augury \\ Wondrous wheel of gulls \\ High under heaven's canopy. \\ Inland they spin \\ On silent, invisible wind, \\ Wheeling and wheeling, \\ Ushering and bowing in \\ Some prima ballerina \\ Retreating faithfully and with servile grace \\ Before their divine mistress.
}

\section{Mid-Country Blow}

All night and all day the wind roared in the trees,

Until I could think there were waves rolling high as my bedroom floor;

When I stood at the window, an elm bough swept to my knees;

The blue spruce lashed like a surf at the door.

The second dawn I would not have believed: 
The oak stood with each leaf still as a bell.

When I looked at the altered scene, my eye was undeceived,

But my ear still kept the sound of the sea like a shell.

4. Are the images clear, complete and organically related? (The first poem has too many vague, unconnected images; the second also has vague images but they are controlled. The third poem loses direction in clashing violent images.)

\section{Riderless Horses}

An owl on the dark waters

And so many torches smoking

By mossy stone

And horses that are seen riderless on moonlit nights

A candle that flutters as a black hand

Reaches out

All of these mean

A man with coins on his eyes

The vast waters

The cry of seagulls

For the Anniversary of My Death

Every year without knowing it I have passed the day

When the last fires will wave to me

And the silence will set out

Tireless traveller

Like the beam of a lightless star

Then I will no longer

Find myself in life as in a strange garment

Surprised at the earth

And the love of one woman

And the shamelessness of men

As today writing after three days of rain

Hearing the wren sing and the falling cease

And bowing not knowing to what

Writing a Poem in the Kitchen

I come into the kitchen

lugging the huge decapitated

hippopotamus head

of the typewriter

to the table where I place it

between us like 


\author{
some raft \\ over which I crawl \\ on my vowels and consonants \\ toward the horizon \\ of her beckoning smile.
}

5. Does the sequence of lines carry the reader along quickly but clearly? ("The Red Door" bores the reader by its meandering. "The Hanging Man" moves so fast that the reader may be left behind.)

The Hanging Man

By the roots of my hair some god got hold of me.

I sizzled in his blue volts like a desert prophet.

The nights snapped out of sight like a lizard's eyelid:

A world of bald white days in a shadeless socket.

A vulturous boredom pinned me in the tree.

If he were I, he would do what I did.

6. Do generalizations grow out of the experience in the poem, or do they come too soon and, therefore, seem imposed? (In "The Pine Bough" a social meaning is awkwardly imposed upon the image. "For the Anniversary of My Death" begins with a generalization and then makes it concrete. The last lines of "Mid-Country Blow" present an honest, believable conclusion to the storm experience as seen by the boy. In the first poem below, the second stanza comes too soon. In the second poem the philosophizing seems to be forced upon the unhappy child.)

Ball Poem

1

Children are bouncing balls off concrete.

In their hard conceit they have already forsaken all others.

They love only their balls and their balls love back.

2

Mindlessly lost in a contract of give and it shall be given, they work their singlemindedness into a blessing. Indeed the balls' beatitudes cheer the heavy air.

3

All afternoon the children play the wall.

Their balls beat gladly on the good cement.

Each one returns unlike the way it went. 


\section{The Ball Poem}

What is the boy now, who has lost his ball,

What, what is he to do? I saw it go

Merrily bouncing, down the street, and then

Merrily over-there it is in the water!

No use to say ' $O$ there are other balls':

An ultimate shaking grief fixes the boy As he stands rigid, trembling, staring down

All his young days into the harbour where

His ball went. I would not intrude on him,

A dime another ball, is worthless. Now

He senses first responsibility

In a world of possessions. People will take balls,

Balls will be lost always, little boy,

And no one buys a ball back. Money is external ...

7. Does the poet's tone of voice seem appropriate to the poem's situation? (The tone of "The Ball Poem" is an unpleasant combination of mockery and serious lament. In their different ways, the tones of "Storm's Timeless Augury," "Riderless Horses" and "The Crucifix" seem inflated and prophetic.)

8. Would the poem be better if it were shorter? ("Ball Poem," for example, might be improved by omitting the second stanza. "Storm's Timeless Augury" would be better without the last four lines, the ballerina comparison. Cutting out a few images could improve "Riderless Horses.")

9. Do any echoes or imitations of other poets become evident? (The first ball poem may be inspired by the second. "Cottonmouth Country" echoes Lowell and Eliot. "Sundown" owes too much to Roethke.)

Cottonmouth Country

Fishbones walked the waves off Hatteras.

And there were other signs

That Death wooed us, by water, wooed us

By land: among the pines

An uncurled cottonmouth that rolled on moss

Reared in the polluted air.

Birth, not death, is the hard loss.

I know. I also left a skin there.

\section{Sundown}

I slide along the edges

like I can.

What I fear most

I love most. 
The edges have body

a body I touch

now and then...

10. Can the reader feel a strong impulse behind the poem, or do the words seem to be skillfully arranged to give the impression of important emotions? (It is hard to find any drive toward expression in "The Pine Bough," a small event that is magnified, or in "Storm's Timeless Augury," a rhetorical exercise. In the two ball poems the poets seem intent upon finding lively examples for vague ideas. "Cottonmouth Country" may have an experience behind it, but it's covered by unconnected statements.)

11. Does the poem give you the feeling it could be figured out, even if it's not completely intelligible upon first and second reading? ("The Hanging Man" has that potential. "The Crucifix" also seems figurable but with more effort than reward.)

12. Is the poem comparable to the poet's best work? Or to the best poems on the same general topic? (By the first question, all the bad examples would be disqualified. Their writers have done better work. By the second, "For the Anniversary of My Death," and "The Cuttings" might qualify, although such a judgment is necessarily subjective.)

13. Can you remember anything about the poem a while after reading it? If not, and you gave the poem a chance, it probably means that the poem is in no way memorable. The reader of this essay can try this test for himself: Which of the examples do you recall most clearly?

\section{What are the problems in judging contemporary poetry?}

Looking back at our list, we can see that the criteria for contemporary poetry would be useful for judging any poem in English, although they would be weighted differently at different times. An eighteenth century critic, for example, might not worry as much about conventional diction (3), vague imagery (4), imposed generalizations (6) or the imitation of other poets (9). However, a modern reader of Augustan verse likely comes to it with such criteria in mind, at least until he realizes how they apply to different poetic conventions. They may not be universally relevant, but our criteria are based on common standards of unity, coherence and complexity. They connect these standards to the contemporary interest in colloquial language, strong images, honesty instead of wit, more depth than surface, and clarity before complexity.

People often say that judging contemporary arts is very difficult or impossible. For poetry I think the opposite is true-judging current poems should be easier than judging earlier poems. In Parnassian terms we may not know if Lowell and Roethke will rank alongside Keats, Yeats and Eliot in literary minds of the 21st century. But how useful would it be to know? One reason we find contemporary poetry hard to judge is that past poetry has already been judged for us by genera- 
tions of editors, critics and readers. We can accept their work as our own. Only the poetry of today forces us to judge for ourselves in the absence of received opinion.

Judging the poetry of our own time is easier for several reasons. First, since we read and speak it daily, our sense of its language must be keener than even a trained scholar can attain for an earlier time. Poets write in or against daily speech and writing. We know its connotations instinctively, so we can spot rhetoric and inflation where we would likely miss it in earlier verse. For instance, "Storm's Timeless Augury" might be read as a fine poem if written in 1870. "The Pine Bough" would be acceptable if dated 1890. But as contemporary readers of these poems we know right away they are falsely literary. Their writers have ignored the American language of the 1960's.

Second, contemporary poems apply to our experience more directly than past poems can. Our sense of how people relate to each other, of what they may say and think in a given situation, can never be as sure for the Victorian era, for example. This means we can spot the pretentious, the overdramatized and the trivial in contrast to what honestly illuminates our lives. Such relevance may not be poetry's ultimate value, yet going by our tests of interest and learning, a generous view of such illumination may be the best guide we can have in judging. From our experience we notice the false profundity and imposed interpretations of the two "Ball Poems."

Third, the availability of mediocre poetry today can help us to clarify the distance between the worst and best. To know how much better Yeats was than most of his contemporaries takes library research. To recognize Roethke's superiority you only need to pick up the latest copy of The New Yorker or Poetry. Poetry in manuscript is not hard to find and read today, while what we can read of earlier poetry depends on what was published. Not that mediocre poetry abounds today as it did not before. The anthologies just haven't left it behind yet.

Fourth, because we're close to its composition, poetry today seems less immutable than the poetry of the past. Readers are more inclined to think how a poem could be better. Poets often respond to editors' or friends' suggestions for improving their poems. At times they admit to uncertainty about a poem's success. Also, from frequent public readings, we may come to know the poet speaking his own poems, unsheltered by the printed page. Long after such a reading, the poet's voice accompanies our reading of his books. With contemporary poetry we can be more aware of the creator and his poetic options-the way his poems express his life.

Fifth, because we can know what is in the air, we can guess what influences work on a poet, what he accepts and rejects in the poetry surrounding him. In terms of these influences, we can identify originality in contemporary poetry, while knowledge of influences on earlier poetry might take years of scholarly work. Work and reading are necessary, of course, but we don't need to reconstruct the literary era of which we are a part. Intuition and instinct are more reliable tools in judging current poetry than in judging poems of the English Romantics, for example. 
If most conditions favor the accurate judging of contemporary poetry, a few risks remain. Knowing a poet personally or at second hand may cloud one's judgment. It is human nature to underrate the accomplishments of those we don't like, and overrate what our friends do. This personal element often appears when poets today write as critics. The strength of poet-critics is they can see how a poem is put together. Their weakness is a tendency to write about others' poems in terms of their own. The closer it comes to their own work, the better they like it (unless it comes too close).

Since poetry grows out of modern life, poetic styles can get confused with life styles. Geography and jobs tend to divide contemporary American poetry. The Field editors try to be open to all kinds of poems, but somehow we don't favor many second-rank poets of the New York School or the Black Mountain School, to use two awkward labels. We find it hard to judge only the excellence of poems and not kinds of poems, their ideas, experiences and techniques. Because we live in the rural midwest, we see more in nature than a New Yorker might. Because we are married and have children, poems dealing with family situations may interest us more than they would other editors. Such inclinations may be inevitable, yet it is well to keep them in mind when judging poems. Another inclination with contemporary poetry is to judge first and understand later. Even academics can be reluctant to give Gary Snyder, say, the careful study that T. S. Eliot receives from them automatically. More and better interpretations of these poets will help to change what is sometimes almost condescension toward the unestablished.

In conclusion, when we connect the theory of judging poems to its practice as illustrated by one poetry magazine, we see that criteria are most useful when implicit and intuitively applied. During the sifting process, the marginal poems, not the obviously successful or unsuccessful poems, prompt critical analysis. For most poems the two simple tests of interests and learning suffice. Only when their results seem uncertain do our editors apply more precise criteria: line rhythm, reinforcing sound, energetic words, clear and connected images, steady movement, honest generalizing, a consistent voice, justifiable length, originality, strong controlling impulse, intelligibility, relative excellence and memorability. If judging poems is the intuitive application of these general and technical criteria, then it should work best where our knowledge of the language, the social and personal context is most certain and complete-on contemporary American poems.

\section{Poems Quoted in Part II}

1. “The Pine Bough," Richard Aldridge, An Apology Both Ways (Bloomington, Ind.: Indiana Univ. Press, 1957), p. 35.

"The Cuttings," Theodore Roethke, Collected Poems (Garden City, N. J.: Doubleday \& Co., 1965$)$, p. 37.

"The Red Door," Ted Hall, Shenandoah, Vol. XXIV, Spring, 1973, no. 3, pp. 16-18.

2. "The Crucifix," Robert Lowell, Lord Weary's Castle and The Mills of the Kavanaughs (Cleveland: World Pub. Co., 1961), p. 48.

"The Well of Holy Heaven," Lewis Turco, Poetry Northwest, Vol. VIII, no. 1, Spring, 1967, pp. 22-23.

"Full Moon and Little Frieda," Ted Hughes. 
3. "Storm's Timeless Augury," William Davis, Janus (San Francisco: The Auerhahn Society, 1967), p. 14.

"Mid-Country Blow," Theodore Roethke, Collected Poems (Garden City, N. J.: Doubleday \& Co., 1965), p. 12.

4. "Riderless Horses," Robert Bly, The Light Around the Body (New York: Harper \& Row, 1967), p. 58.

"For the Anniversary of My Death," W. S. Merwin, The Lice (New York: Atheneum, 1967), p. 58.

"Writing a Poem in the Kitchen," Greg Kuzma, Sumac, Vol. 2, nos. II \& III, Winter/Spring, 1970, p. 28.

5. "The Hanging Man," Sylvia Plath, Ariel (New York: Harper \& Row, 1966), p. 69.

6. "Ball Poem," Stanley Plumly, In the Outer Dark (Baton Rouge, La.: Louisiana State Univ. Press, 1970), p. 12.

"The Ball poem," John Berryman, in The Contemporary American Poets, ed. Mark Strand (Cleveland: World Pub. Co., 1969), p. 31.

9. "Cottonmouth Country," Louise Glück in The Contemporary American Poets, ed. Mark Strand (Cleveland: World Pub. Co., 1969), p. 96.

"Sundown," Floyce Alexander, Sumac, Vol. 1, no. 3, Spring, 1969, p. 85. 